\title{
ТУРЕЦЬКІ ДЖЕРЕЛА ФОРМУЛИ НЕЗМІРНОСТІ У СЕРБСЬКІЙЛІРО-ЕПІЧНІЙ ТРАДИЦІї
}

\section{О. О. Микитенко}

Микитенко О. О. Турецькі джерела формули незмірності у сербській ліро-епічній традиції. У статті йдеться про позначену високою частотністю формулу, спрямовану на глорифікацію образу, із прагматикою передачі нездатності уславити/перерахувати загиблих. У сербській фольклорній традиції формула набуває виразного історико-епічного звучання і пов'язується з топосом Косового поля, а також фіксується у народній ліриці. Лексико-семантичні особливості формули, витоки якої у книжній культурі, свідчать про турецькі джерела стосовно сербського варіанту.

Ключові слова: сербський фольклор; плачі; формула незмірності; турецькі джерела.

Микитенко O. О. Турецкие источники формулы неизмеримости в сербской лиро-эпической традиции. В статье речь идет о имеющей высокую частотность формуле, направленной на глорификацию образа, с прагматикой передать неспособность прославить/перечислить погибших. В сербской фольклорной традиции формула получает выразительное историко-эпическое звучание и связывается с топосом Косового поля, а также фиксируется в народной лирике. Лексико-семантические особенности формулы, которая происходит из книжной культуры, свидетельствуют о турецких источниках относительно сербского варианта.

Ключевые слова: сербский фольклор; плачи; формула неизмеримости; турецкие источники.

Mykytenko $O$. $O$. Turkish sources of the formula of inexpressibility in Serbian lyric and epic folklore tradition. The article deals with the high frequency formula to glorify the person, with pragmatics to tell about impossibility to bring fame to those who fell in the battle and to enumerate them. In the Serbian folkloric tradition formula gets the expressive historical and epical meaning and is bounded with the topos of Kosovo field, at the same time it is mentioned in folk lyric poetry. The lexical and semantic peculiarities of the formula, with its origin in the scribe tradition, testify to Turkish sources according to Serbian variant.

Keywords: Serbian folklore; laments; formula of inexpressibility; Turkish sources.

У сербській народнопоетичній традиції, зокрема у ліро-епіці, особливе місце посідають формули уславлення загиблих. Одним із часто вживаних прийомів глорифікації $\epsilon$ формула неможливості перерахувати імена загиблих та нездатності гідно оплакати героїв, аби зберегти їхню пам'ять для нащадків. Ця гіпербола, у якій неспроможність плакальниці порівнюється 3 морем, що перетворилося на чорнило, та небом, яке стало аркушем паперу, є клішованим засобом у балканській фольклорній традиції і часто використовується у народних піснях-плачах. Дотримуючись традиційних канонів, народні плакальниці постійно вносять власне індивідуальне бачення як у композиційну структуру тексту, так і в його поетичне вираження. Разом із тим, в одному тексті збірника В. Караджича плакальниця спочатку каже про нездатність уславити загиблих, а потім - «тим більше перелічити їх», що свідчить як про константність риторичної формули, яку, можливо, було вжито механічно, або пояснюється тим, плакальниця просто не вміла рахувати і висловила це в поетичній формі:

"Да је зала црно море, црној мене!

Да је књига равно поље, рано браћо!

Ја вас не бих искитила, китна браћо!

А камо ли побројила, бојна браћо!»'

Імпровізація, що свого часу так вразила М. Перрі та А. Лорда, наявна в краї із сильною епічною традицією як природний дар, яким носії фольклорної традиції користуються надзвичайно широко. Імпровізіція має тут, як неодноразово зауважували дослідники, «складний характер, сполучаючи дивовижну свободу з величезною творчою фантазією» ${ }^{2}$, унаслідок чого епічна пісня створюється під час усного виконання. У середовищі, де письмова традиція складалася в постійному життєдайному взаємозв'язку з традиційною духовною культурою та епічною творчістю, форма десятискладового вірша як наслідок багатовікової традиції стала звичайною формою мовного вираження та тією мовною моделлю, що визначала закономірності функціонування різних жанрів фольклорної творчості. Попри те, що плачі, як правило, складалися у формі восьмискладового вірша (часто із чотири(C) Микитенко, О. О., 2015 
складовим приспівом), форма десятискладового вірша оплакування, як стверджує П. Влахович, надзвичайно широко представлена в багатьох краях Сербії, нерідко становлячи частину довгої епічної пісні як у давній, так і в новішій десятискладовій епічній поезії․

Як показали дослідження, середньовічні твори сербської літератури, що виникли безпосередньо після Косовської битви 1389 р., були складені десятискладовим віршем - «довгим плачовим віршем» сербської поезії (зокрема, оплакування загибелі князя Лазаря). Це стало не лише доказом безпосереднього впливу народної епічної поезії на художню традицію, а й підтвердженням того, що «плачі мусили становити частину первісної народної пісні про Косовську битву», більше того - зумовило вірогідність, що саме 3 оплакування й «виросла вся епопея» ${ }^{4}$.

Така дифузія фольклорних жанрів зумовила активне використання художніх прийомів, серед них формули незліченності, паралельно у ліричній та епічній традиції сербів. У найзагальніших рисах семантика традиційної формули, в якій глорифікація образу досягається завдяки системі поетичних тропів, зокрема паралелізму поетичних образів, стосується протиставлення книжка / письмо - природа. Структурно формула будується з трьох або двох рядів порівнянь, при цьому елементи, що семантично належать до писарської майстерності (папір, чорнило, перо), зіставляються зі сферами природи (полем, морем, деревом) з метою абсолютизації концептів. Разом із тим функціонально метафоричне узагальнення має на меті інший художній троп, а саме - гіперболу, в основі якої лежить порівняння, що граматично визначається як співвідношення суб'єкт-об'єкт, із граматично зазначеною суперіорністю об'єкта. Порівняння, виражене дієсловом умовного способу дії, імплікує негацію, тим самим висловлюється негативне порівняння: чорнило не $\epsilon$ морем, лист паперу не $\epsilon$ полем, перо не $\epsilon$ ялицею. Гіпербола будується на умовному способі дії із майбутнім значенням «якби..., то і тоді я б вас не оплакала». Виконавиця вдається до прийомів змалювання вселенського горя, і саме в цьому контексті з'являється епічний топос серб. сиво / равно поље - ирно / сиње море.

Структурна стабільність формули, яку демонструють тексти різночасової фіксації, пов'язана з її синтаксичною закритістю як цілісної синтагматичної одиниці. Семантична визначеність формули залежить від дієслівного об'єкта, поданого у формі заперечення, чим досягається значення гіперболи незмірності, тобто неможливості перерахувати / описати / оплакати / уславити загиблих:

«Да ј’ хартија као поље,

А мастило као море,

Не бих могла описати,

Ни набројат све подвиге» ${ }^{6}$;

«Da j’ murećep sinje more,

Da je pero vita jela,

Da je papir velje polje,

Bih sve more potrošila,

A još ne bih tužnu žalost

Pobrojila!»

«Да је море плава боја,

А хартија што је поље,

Да је рука учевњака

И не би ве побројио.... ${ }^{8}$;

«Да је дивит сиње море

А артија дуго поље,

Десна рука писарева,

Млада момка, Милована,

Не бих јаде пописала...»";

«Да је карта сиво поље,

А мастило сиње море,

Мудра глава Милошева

И Вајкова,

Хитра рука писарева

Једва би вас пописала

А камоли ја кукала....» 
Гіпербола незмірності повністю відповідає визначенню формули, яку ще в 1909 р. запропонував А. ван Геннеп, один з учителів М. Паррі. За визначенням А. ван Геннепа, критерій формульності певного виразу треба вбачати у ступені реалізації очікування, коли за певним словом (або словосполученням) має з'явитися інше слово або сполучення слів. Чим вищий цей ступінь, тим вищою є вірогідність того, що перед нами - клішований текст, інакше кажучи, формула ${ }^{11}$. Таким самим очікуванням можливого позначається й епічний топос поле/море, який, на відміну від місия-знаку, не має символічного значення, передбачає лише можливість дії, проте вірогідність того, що має статися, майже дорівнює відомому. Певна невизначеність чи, інакше кажучи, широта такої дефініції формули нейтралізується конкретною структурно-композиційною моделлю, у межах якої дана формула використовується як відповідний художній прийом.

Як відомо, у традиційній народній культурі простір, як і час, має семантику, є сакралізованим і містить систему вартостей, головними координатами яких $є$ життя і смерть ${ }^{12}$. Включені в архетипові уявлення, концепти «море» і «поле» $є$ стереотипними образами різних жанрів і характерними константними моделями фольклорної топіки. У розглядуваній формулі поєднання «море - поле» $є$ обов'язковими елементами композиційної структури тексту, чим окреслюється найширший - такий, що належить до концепту природи, - сегмент узагальнення, на відміну від іiі варіативних компонентів, які окреслюють семантичну сферу культури (серб. мудра глава, десна / хитра рука, рука учевњака). Відповідні сполучення іменників 3 постійними загальнофольклорними епітетами сиње / ирно (море) та дуго / веље / равно / сиво (поље) є константними як для фольклору, так і для давньої літератури, що дає підстави твердити про неактуальність тут кольору. Так, дослідники давньоруської літератури щодо постійних колористичних епітетів, у тому числі у складі фразеологізованих сполучень типу чорний ворон, сірий вовк, синє море, жовті піски, зелені луки тощо, зазначають, що в подібних зрощеннях, або «синкретичних уявленнях», колір давно втратив свою чуттєву дієвість, через що такі епітети можна вважати «нейтральними колористичними характеристиками» ${ }^{13}$. Проте, будучи нейтральними і постійними, ці й подібні до них фольклорні епітети містять певне символічне значення або передають абстрактну оцінку. Зокрема, проведений на матеріалі білоруських замовлянь аналіз показав, що за допомогою сполучень синєє море або чисте поле та ін. як «максимально безкінечних» створюється образ «міфологічного центру», а також моделюється локус «того світу» як просторового континууму ${ }^{14}$.

Для нас важливо, що фольклорна поетика, поєднуючи такі сполучення в межах одного тексту, максимально підсилює їхні негативні семантичні конотації, що знаходить яскраве підтвердження на матеріалі сербських поховальних пісень-плачів, де ад’єктивне поєднання чорне море відповідає загальному звучанню, виявляючи властиву для тексту оплакування палітру, де чорний є колористичною домінантою.

Широке використання формули незмірності у поховальній поезії сербів спричинене, як ми зауважили, специфікою функціонування просторової моделі в епічній поезії, де лише модель простору будується на відношеннях не опозиції, а еквівалентності (смерть $=$ низ $=$ темрява $=$ вогонь $=$ вода і под. $),$ у зв'язку з чим саме просторові метафори стають стабільним і майже ідеальним носієм тієї кодової інформації, що співвідноситься iз міфопоетичними конотаціями обрядового тексту. Тим самим формула як інтегральна частина тексту визначає також його комунікативні межі під час виконання. Зважаючи на те, що рівновага між «традицією і індивідуальною майстерністю» значною мірою залежить від можливостей дестабілізації внутрішніх меж тексту, які є місцями зіткнення формульності й оригінальності як двох протилежних начал епічної поезії ${ }^{15}$, у процесі створення та виконання епічного твору співець досягає найвищої креативної свободи і творчої оригінальності, він здатний максмимально використати можливості, які надає йому традиція, а на рівні тексту - сама його структура. Розуміння формульності як найважливішої властивості усного творення, що користується формулою як «основним засобом вираження й художнього оформлення» ${ }^{16}$ тексту, передбачає надзвичайно важливу iii роль на рівні мікро- і макротексту, тобто як у межах окремого твору, так і в контексті епічної традиції загалом.

У своїх дорожніх нотатках «Листи з Італії» Любомир Ненадович, згадуючи перебування П. Негоша в Італії у 1850-1851 pр., наводить слова сербського владики, звернені до одного англійського лорда. Подарувавши йому свій портрет, П. Негош мовив: «Коли 
повернетесь до багатого Лондона і покажете цей портрет своїм друзям, не кажіть їм: це правитель щасливого народу... Скажіть їм: серби могли б перемогти турків, та не можуть умилостивити вас, християн... У нас, сербів, $є$ пісня, що каже: якщо і море перетворилося б у чорнило, а небо - в аркуш білого паперу, то й тоді неможливо було б описати наші страждання. Бо то є занадто мале місце для нашого горя...» ${ }^{17}$. Парафразувавши слова народної пісні, П. Негош використав метафору письма, щоб передати те, чого не можна передати, і що ввійшло в національну історію як трагедія Косова.

Сербська епічна традиція є, як відомо, традицією оспівування Косова, яке можна вважати прецедентним текстом у фольклорному дискурсі. Поетична традиція сприяла тому, щоб це місце стало сакральним для народної пам'яті, протягом століть залишалося символом національної долі, мірилом самовідданості, відваги й віри. Косово в народній свідомості набуло не лише часового і просторового виміру, але й стало колективним моральним імперативом. Мотив Косова міститься - прямо або опосередковано - чи не в кожному епічному творі. Про алюзію Косова на рівні поетичної формули можемо говорити і тоді, коли йдеться про уславлення загиблих, оскільки завданням поховального тексту є прирівнювання окремої смерті до прецедентної. Клішованість моделі формули незмірності та сталість уявлень, які вона втілює, стали причиною звернення до неї також в сучасному публіцистичному дискурсі, коли йдеться про смерть визначної особи. Зокрема, цю формулу використав О.-Б. Мерін у некролозі на смерть Й.-Б. Тіто: «Згадуючи Тіто, я повторюю слова: Хто дав би мені простір неба за пергамент, морські глибини за чорнило, листя й трави за перо, аби вповні описати горе.... ${ }^{18}$.

Витоки цієї риторичної формули знаходимо в книжній культурі. Будучи теологічною формулою, вона семантично пов'язана з божественною мудрістю як логосом, яка $є$ безмежною. У народнопоетичну традицію Європи формула прийшла через візантійську традицію з канонізованих вітхозавітних текстів, поєднавши риси, успадковані від трьох етнорелігійних спільнот - романської, арабської та іудейської ${ }^{19}$. Маючи широке використання в церковній літературі, формула в різноманітних інтерпретаціях переходила у книжну традицію і була відома багатьом ученим людям свого часу, серед них П. Негошу. Достатньо пізня інтерпретація, яка йому належить, вирізняється тим, що в європейській літературній традиції XII-XIX ст. немає жодного іншого прикладу залучення формули для передачі національної трагедії народу.

Інтерпретації формули в європейській фольклорній традиції, на думку науковців, розділяються на дві основні групи. До першої належать ті тлумачення, що пов'язуються 3 канонічними релігійними поняттями й уявленнями, до другої - тлумачення зі сфери світського життя, серед них - опис ідеалізованої жінки, кохання, але також колективне почуття історико-національного страждання. Хоча тема страждання і знайшла своє втілення в окремих традиціях, центральне місце посідають саме ліричні обробки формули.

Лірично-любовна інтерпретація формули є домінантною в ліричній поезії балканських народів та в регіоні східного й західного Середземномор'я. Відомі ії румунські, албанські, новогрецькі, турецькі й інші варіанти. Широкої популярності здобули її літературні обробки, зокрема в інтимній ліриці європейських романтиків (зокрема, вірш Г. Гейне «Сповідь», сербською мовою перекладений А. Шантичем). Сербський варіант народної лірики, що має назву «Љубавни растанак» В. Караджич подав у своєму збірнику «Народна Србска Пјеснарица» (1815). Ряд варіантів наводить Т. Джорджевич, серед них із «Ерлангенського рукописа», а також по два записи з Боснії та Славонії, в яких відчутний вплив мусульманської епічної традиції ${ }^{20}$.

Запис, представлений В. Караджичем, вочевидь, мав широке побутування. Це яскравий приклад народної сербської любовної поезії, яка метафорою квітів говорить про розставання двох закоханих. В уявному діалозі квітів (зумбул 'геацинт' та када 'маргаритка') використано формулу неможливості описати безмежні любовні страждання двох закоханий. Формула містить усі три компоненти порівнянь: небо / аркуш паперу; гора / перо; море / чорнило. Лексичні особливості (тюркізми мурећеn 'чорнило' і калемови 'перо'), лексичне зрощення лист артије (замість звичайного у Негошевому парафразі лист књиге бијеле), а також характерне для любовної лірики почуття любовного томління і болю (тур. dert), метафорика квітів вказують на турецькі джерела формули.

Форма турецьких мані, написаних двовіршем за схемою суміжного римування, спричинила усічену конструкцію для формули незмірності, у якій, як правило, було збережено 
лише порівняння чорнила з морем. Водночас мусульманська любовна лірика у Боснії і Герцеговині, представлена жанром пісень любовної пристрасті, млості і щему - севдалинок (від араб. sawda 'чорна жовч'), має широкі жанрові та художньо-поетичні паралелі у фольклорі інших балканських народів. У текстах оспівується страждання і сум через кохання, відчутним є вплив орієнтальної традиції, вони наближаються до оплакування, що уможливлює й використання відповідних художніх прийомів. Любовно-еротичні конотації одержує метафора 'пера' i 'чорнила', тлумачення якої перебувають у межах інтерпретацій теологічних алегорій.

Ще наприкінці 30-х рр. XX ст. Т. Джорджевич погодився 3 думкою Р. Келера, що «Коран» «позичив» формулу незмірності з «Талмуда», а для широкого побутування ії на заході значну роль відіграла єврейська духовна пісня (Pfingslied), яка, починаючи з XI ст., щорічно співалася у синагогах ${ }^{21}$. Разом із тим для фольклорної традиції сербів відчутнішим було турецьке посередництво, яке стало джерелом формули у сербській ліро-епіці. Сербський варіант у В. Караджича, запис якого припадає на початок XIX ст., найвірогідніше, спирається саме на турецькі джерела.

Отже, у сербській фольклорній традиції формула незмірності знайшла втілення як у любовній ліриці, так і в поховальних піснях-плачах виразного історико-епічного звучання. При варіюванні інших компонентів формули топос моря виявився найстабільнішим, наявним в усіх їі інтерпретаціях, тоді як замість звичайного в ліриці порівняння небо - аркуш nanepy у поховальних плачах послідовно з'являється порівняння поле - аркуш паперу, де топос поля має конотації з епічним Косовим полем, тим самим семантично залишаючи формулу у вимірі безмежності і незнищенності людського буття.

${ }^{1}$ Караиић Вук Cm. Етнографски списи // Сабрана дела Вука Караџића. - Београд: Просвета, 1972. - Књ. 17. - С. 279.

${ }^{2}$ Пидаль Р.М. Югославские эпические певцы и устный эпос в Западной Европе // Известия АН СССР: Сер. лит. и яз. - 1966. - Т. 25. - Вып. 2. - С. 106.

${ }^{3}$ Влаховић П. Неки новији облици наших народних тужбалица // Народно стваралаштво-Folklor. - 1970. - Св. 35-36. - С. 111.

${ }^{4}$ Милошевић-Ђорђевић $H$. Српске народне тужбалице у середњовековним списима о кнезу Лазару и Косовској бици // Књижевност и језик. - Београд, 1994. - Год. 41. - Бр. 3-4. - С. 9.

${ }_{5}^{5}$ Микитенко O. Топосьт ирно море в сръбските и черногорските погребални оплаквания // Брегът-морето-Европа. Сб. с матер. от Междунар. науч. конф. „Брегът, морето и Европа. Модели на интеркултурна комуникация“. - София: Академично издателство „Проф. Марин Дринов“, 2006. - C. $105-113$.

${ }^{6}$ Мартиновић Н. С. Мјесто тужбалице у фолклору Народне револуције и Ослободилачког рата // Зб. радова САН. - Београд, 1960. - Т. 68. - Књ. 3. - С. 465.

${ }^{7}$ Zbornik za narodni život i običaje Južnih Slavena. - Zagreb, 1964. - Knj. 42. - S. 11.

${ }^{8}$ Српске народне тужбалице из збирке Новице Шаулића. - Београд: Графички институт "Народна мисао”, 1929. - Књ. 1. - Св. 1. - № 63.

${ }^{9}$ Там само. - № 48.

${ }^{10}$ Русский фольклор: Материалы и исследования. - М.; Ленинград: Наука, 1959. - Т. 4. - С. 396.

${ }^{11}$ Gennep A. van. La Question d'Homere. - Paris, 1909. - P. 13.

12 Славянские древности: Этнолингвист. словарь: В 5 т. / Под ред. Н.И. Толстого. - М.: Международные отношения, 1995. - Т. 1. - С. 450.

${ }^{13}$ Панченко А.М. О цвете в древней литературе славян // Литературные связи древних славян: Тр. Отдела древнерус. лит. - Ленинград, 1968. - Т. 23. - С. 11-12.

${ }^{14}$ Агапкина Т.A. Эпитет в белорусских лечебных заговорах: функции и семантика // Признаковое пространство культуры. - М.: Индрик, 2002. - С. 306.

${ }_{15}^{15}$ Детелић М. Митски простор и епика. - Београд: Danex, 1992. - С. 314.

${ }^{16}$ Pešić R. Narodna književnost / R. Pešić, N. Milošević-Đorđević. - Beograd: Vuk Karadžić, 1984. - S. 85 .

${ }^{17}$ Ненадовић Љ. Писма из Италије. - Београд: Српска књижевна задруга, 1907. - С. 19-20.

${ }_{18}$ Vidaković-Petrov K. Istorija jedne retoričke formule // Књижевна историја. - Београд, 1985. - Год. 18. - Св. 67-68. - S. 204.

${ }^{19}$ Там само. - S. 185.

${ }^{20}$ Ћорђевић Tux. Р. Белешке о нашој народној поезији. - Београд, 1939. - С. 178-179.

${ }^{21}$ Там само. - C. 180. 